Published in final edited form as:

Toxicol Appl Pharmacol. 2007 November 1; 224(3): 241-248.

\title{
p53 and the Pathogenesis of Skin Cancer
}

\author{
Cara L. Benjamin and Honnavara N. Ananthaswamy \\ Department of Immunology, The University of Texas M. D Anderson Cancer Center, Houston, \\ Texas, U.S.A., Address: P.O. Box 301402, Unit \#902, Houston, Texas 77030-1903 U.S.A. Phone: \\ 713-563-3247, Fax: 713-563-3280, Email: hanantha@mdanderson.org
}

\begin{abstract}
The p53 tumor suppressor gene and gene product are among the most diverse and complex molecules involved in cellular functions. Genetic alterations within the p53 gene have been shown to have a direct correlation with cancer development and have been shown to occur in nearly $50 \%$ of all cancers. p53 mutations are particularly common in skin cancers and UV irradiation has been shown to be a primary cause of specific 'signature' mutations that can result in oncogenic transformation. There are certain 'hot-spots' in the p53 gene where mutations are commonly found that result in a mutated dipyrimidine site. This review discusses the role of p53 from normal function and its dysfunction in pre-cancerous lesions and non-melanoma skin cancers. Additionally, special situations are explored, such as Li-Fraumeni syndrome in which there is an inherited p53 mutation, and the consequences of immune suppression on p53 mutations and the resulting increase in non-melanoma skin cancer in these patients.
\end{abstract}

\section{MOLECULAR INDICATIONS OF THE ROLE OF p53 IN CANCER}

There are multiple genetic alterations that have been shown to have a direct correlation with cancer development. Majority of these mutations can be found within three categories of genes: proto-oncogenes, tumor suppressor genes, or DNA repair genes. A mutation in one of these groups or any combination can cooperate to induce a neoplastic condition. The protooncogenes act as a crucial growth regulators in normal cell division, while the tumor suppressor genes act as negative growth regulators. The p53 tumor suppressor gene is involved in the cell cycle arrest and activation of programmed cell death (Hartwell and Weinert, 1989; Lane, 1992). Mutations in the p53 gene have been detected in $50 \%$ of all human cancers and in almost all skin carcinomas (Basset-Seguin et al., 1994). p53 codes for a 53-kDa phosphoprotein involved in gene transcription and control of the cell cycle by coordinating transcriptional control of regulatory genes (Levine et al., 1991; Vogelstein and Kinzler, 1992; Harris, 1996). Human p53 is a highly conserved 11 exon gene that is located on the short arm of chromosome 17 (Lamb and Crawford, 1986) that is about $20 \mathrm{~Kb}$ in size. The p53 protein forms tetramers through interactions between C-terminal regions of the protein. These tetramers can then recognize specific binding sites on target genes and stimulate their activation. Mutant forms of p53 rarely exhibit mutations in the oligomerization region, but rather have mutations in the DNA binding domain.

Majority of carcinomas have missense mutations that produce a full-length protein with altered function. Often the other allele is lost resulting in loss of heterozygosity ( $\mathrm{LOH}$ ), which is particularly high (40-80\%) in carcinomas of the colon, lung, and bladder (Greenblatt et al.,

Correspondence to: Honnavara N. Ananthaswamy.

Publisher's Disclaimer: This is a PDF file of an unedited manuscript that has been accepted for publication. As a service to our customers we are providing this early version of the manuscript. The manuscript will undergo copyediting, typesetting, and review of the resulting proof before it is published in its final citable form. Please note that during the production process errors may be discovered which could affect the content, and all legal disclaimers that apply to the journal pertain. 
1994). In squamous (SCC) and basal cell carcinomas (BCC) of the skin, the frequency of LOH is much lower with a higher proportion of both p53 alleles being independently mutated (Ziegler et al., 1993; Ziegler et al., 1994). Mouse skin models have shown that standard chemical initiation/promotion protocols results in $\mathrm{LOH}$, where as repeated carcinogen experiments (like UV exposure) results in independent mutations on both p53 alleles (Burns et al., 1991).

\section{ROLE OF p53 TUMOR SUPPRESSOR GENE IN UV-INDUCED NMSC}

Individuals with Li-Fraumeni syndrome inherit a mutation in one allele of the p53 gene (Malkin et al., 1990). These individuals have a high incidence of malignancies including NMSC. This data along with observations that many cancers have a mutated or lost p53 gene, suggests that alterations in either pathway contributes to neoplastic transformation. Inactivation of the p53 gene plays an important role in the induction of skin cancer by UV radiation. Analysis of mutations in the p53 gene has established an unequivocal connection between UV exposure, DNA damage, and skin carcinogenesis. UVB and UVC radiation induces unique types of DNA damage, producing cyclobutane-type pyrimidine dimers (CPD) and pyrimidine (6-4) pyrimidone or (6-4) photoproducts (Setlow and Carrier, 1966; Mitchell, 1988; Mitchell and Nairn, 1989). And it has been shown that $\mathrm{p} 53$ plays an important role in the protection of cells from DNA-damage from UVB exposure (Kuerbitz et al., 1992; Smith and Fornace Jr., 1997). UV-induced DNA damage activates mechanisms for removal of DNA damage, delay in cell cycle progression, DNA repair, or apoptosis by transcriptional activation of p53-related genes, such as p21 (Brugarolas et al., 1995), MDM2 (Kamijo et al., 1998), and Bax. Normally, there is little p53 protein in the cell, but in response to UV damage, high levels of p53 are induced (Hall et al., 1993; Healy et al., 1994). With high levels of p53 protein, there is a G1 arrest, allowing the cellular repair pathway to remove DNA lesions before DNA synthesis and mitosis (Kuerbitz et al., 1992; Zahn et al., 1993) and an increase in apoptosis (Yonish-Roauch et al., 1991; White, 1996). Therefore, p53 aids in the DNA repair or the elimination of cells that have excessive DNA damage (Lane, 1992; Levine, 1997).

An important finding about p53 was the fact that upon UV irradiation, there is an increased half-life of the p53 protein in murine 3T3 fibroblasts (Maltzman and Czyzyk, 1984). Typically, wild-type p53 has a relatively short half-life, but stabilization and elevation of p53 protein levels may signify early events in tumorigenesis. This information is important when considering that M1 leukemia cells arrest at the G1-S and G2-M phases of the cell cycle when irradiated (Kastan et al., 1991; Kastan et al., 1992; Kuerbitz et al., 1992). Additionally, the levels of p53 induction in human skin is proportional to the level of UVB exposure, although there is no correlation between UVB-induced p53 levels and erythema (Healy et al., 1994). Several DNA damaging agents have been shown to induce p53 and growth arrest (Kastan et al., 1992; Fritsche et al., 1993), but only by those agents that induce strand breaks. Pyrimidine dimers alone do not trigger p53 induction unless accompanied by excision repair-associated DNA strand breaks (Nelson and Kastan, 1994).

In UV-induced skin cancer, the frequency of $\mathrm{C}$ to $\mathrm{T}$ transitions is especially frequent at the trinucleotide sequence 5'-PyCG in the p53 gene (Setlow and Carrier, 1966). There are several 'hot spot' mutation sites with in the p53 gene. Data collected from Pfeifer et al. show that of the most commonly mutated sites in 553 five are mutated dipyrimidine in the sequence context 5'-CCG or 5'-TCG (codons 196, 213, 245, 248, and 282). Additionally, they found only 19 5'CCG or 5'-TCG transitions in the target sequence occurring between codons 120 and 290 (Pfeifer et al., 2005). Mouse tumors induced by irradiation with UVB lamps or solar simulators have identified a hotspot mutation at codon 270 of the p53 gene, which correlates to a sequence change from 5'-TCGT to 5'-TTGT (Tommasi et al., 1997). Codon 270 of the mouse p53 gene is the equivalent to codon 273 of the human p53 gene, but there is no dipyrimidine sequence 
at this location. Codon 270 is methylated at the $\mathrm{CpG}$ site and UVB produced the strongest $\mathrm{CPD}$ at the 5'-TCG. Time course experiments have shown that the CPD at this sequence persists longer than average, which suggests that the CPD is responsible for the induction of this mutational hotspot in UV-induced skin tumors (You et al., 2000). In fact CPDs are responsible for majority of mutations induced by UVB irradiation in mammalian cells. Using mammalian cells containing the mutational reporter genes lacI and cIIYou et al. (2001) concluded that CPDs are responsible for at least $80 \%$ of the UVB-induced mutations in this model.

\section{p53 MUTATIONS IN HUMAN PRE-CANCEROUS SKIN LESIONS}

The mutations in $p 53$ gene appear to be an early genetic change in the development of UVinduced skin cancers. Thousands of p53-mutant cell clones are found in normal-appearing sunexposed skin (Nakazawa et al., 1994; Jonason et al., 1996; Ren et al., 1996). There is a high frequency of p53 mutations reported in pre-malignant actinic keratosis (AK) lesions, which are considered to be pre-SCCs. In an AK study by Ziegler et al. (1994), p53 mutations were found at a $66 \%$ frequency and a high proportion of them (23/35) were $\mathrm{C} \rightarrow \mathrm{T}$ transition. Nelson et al. (1994) showed that 8 of $15(53 \%)$ AKs had $\mathrm{C} \rightarrow \mathrm{T}$ transition in p53 gene and Campbell et al. (1993) showed that 40\% (8 out of 20) of individuals with Bowen's disease carried p53 mutations as well. These early findings suggested that p53 mutations may be involved in the malignant conversion of precancerous lesions to SCCs and that mutations in p53 and/or p53 over expression may be used as biomarkers for skin cancer susceptibility. Since then, the presence of $\mathrm{UV}$ signature $\mathrm{C} \rightarrow \mathrm{T}$ and $\mathrm{CC} \rightarrow \mathrm{TT}$ mutations in the $p 53$ gene in human and experimental mouse skin cancers has been well documented (Pierceall et al., 1991b; Kress et al., 1992; Rady et al., 1992; Dumaz et al., 1993; Kanjilal et al., 1993; Sato et al., 1993; Ziegler et al., 1993; Greenblatt et al., 1994; van der Riet et al., 1994; Stern et al., 2002; Bolshakov et al., 2003).

\section{p53 MUTATIONS IN SCC AND BCC OF THE SKIN}

A number of investigators have detected $p 53$ gene mutations in a large proportion of human squamous cell carcinomas and basal cell carcinomas (Pierceall et al., 1991a; Pierceall et al., 1991b; Rady et al., 1992; Dumaz et al., 1993; Moles et al., 1993; Sato et al., 1993; Ziegler et al., 1993; Greenblatt et al., 1994; van der Riet et al., 1994; Ziegler et al., 1994; Stern et al., 2002; Bolshakov et al., 2003). Initial studies by Brash and co-workers (Brash et al., 1991) revealed $p 53$ mutation in 58\% of human SCC. Later studies by Ziegler et al. (1994), and Rady et al. (1992) have demonstrated p53 mutations in human BCCs at 56\% and 50\% frequencies, respectively. Interestingly, Ziegler et al. (1994) found that $45 \%$ of human BCCs contained a second point mutation on the other $p 53$ allele. More recently, Bolshakov et al. (2003) analyzed 342 tissues from patients with aggressive and nonaggressive BCCs and SCCs for p53 mutations. p53 mutations were detected in $66 \%$ BCCs, $38 \%$ of nonaggressive BCCs, $35 \%$ of aggressive SCCs, $50 \%$ of nonaggressive SCCs, and $10 \%$ of samples of sun-exposed skin. About $71 \%$ of the $\mathrm{p} 53$ mutations detected in aggressive and nonaggressive BCCs and SCCs were UV signature mutations (Bolshakov et al., 2003).

Most recently, Agar et al. has examined 8 primary SCCs and 8 pre-malignant solar keratosis lesions for p53 mutations separately, in basal and suprabasal layers of keratinocytes using laser capture microdissection (Agar et al., 2004). They were able to detect UVA-type mutations (A:T $\rightarrow$ C:G transversions) both in SCCs and SC lesions mostly in the basal germinative layer, which contrasted with a predominantly suprabasal localization of UVB-signature mutations in these lesions (Agar et al., 2004). This epidermal layer bias was confirmed by immunohistochemical analyses with a superficial localization of UVB-induced CPD contrasting with the localization of UVA-induced 8-hydroxy-2'-deoxyguanine adducts to the basal epithelial layer. The basal location of UVA- rather than UVB-induced DNA damage and 
mutation suggests that UVA component of solar radiation is an important carcinogen in the stem cell compartment of the skin.

Analyses of mouse skin cancers induced by UV radiation have provided strong evidence for the involvement of p53 mutation in the pathogenesis of UV-induced murine skin cancer. Analogous to human skin cancers, UV-induced mouse skin cancers also display p53 mutations (Kress et al., 1992; Kanjilal et al., 1993; Dumaz et al., 1997; Ananthaswamy et al., 1998), although the frequency of mutations and the exons in which they occur differ among mouse strains, for reasons that are not yet clear. For example, in our study, $p 53$ mutations were detected at $70-100 \%$ frequency in UV-induced SKH-hr1 and C3H mouse skin tumors, respectively (Kanjilal et al., 1993; Ananthaswamy et al., 1998). In contrast, 20\% of SCC from SKH-1/hr hairless mice and $50 \%$ of SCC from BALB/c mice exhibited $p 53$ mutations in another study (Kress et al., 1992). Nonetheless, most of the mutations detected in UV-induced mouse skin tumors were $\mathrm{C} \rightarrow \mathrm{T}$ and $\mathrm{CC} \rightarrow \mathrm{TT}$ transitions at dipyrimidine sites, like those found in human skin cancers, and most were located on the non-transcribed DNA strand.

Further evidence for the involvement of mutations in p53 on the development of cancer is supplied by studies on p53 knockout mice. Heterozygous (+/-) and homozygous (-/-) p53 mice have been shown to develop spontaneous tumors of both primary lymphoid malignancies and various sarcomas (Donehower et al., 1992; Jacks et al., 1994). Ionizing radiation can enhance the frequency of these tumors even with a single dose (Kemp et al., 1994). Interestingly, these mice failed to develop skin tumors. Chemical induction of skin cancer on these mice did not yield an increase in the frequency of papillomas, but there was an enhanced progression from papillomas to carcinomas compared to wild type mice (Kemp et al., 1993). Since there is a strong association between UV-induced skin cancers and p53 mutations, studies using congenic p53 mutant mice and UV-irradiation revealed that heterozygous mice had increased susceptibility to skin cancer induction and p53-/- mice were at an even greater risk of developing skin cancer. Tumors in the heterozygous (+/-) mice were predominantly sarcomas, while the tumors from homozygous (-/-) mice were mostly squamous cell carcinomas associated with premalignant lesions resembling actinic keratosis (Jiang et al., 1999). Point mutations in the p53 gene affect the tumor susceptibility differently than allelic loss. Point mutations are generally associated with early stages of skin tumors, while allelic loss enhances tumor development at high levels of UVB exposure and increases progression of skin tumors to a higher malignancy (van Kranen et al., 2005).

\section{P53 MUTATIONS IN NMSC OF PATIENTS WITH XERODERMA PIGMENTOSUM AND RENAL ALLOGRAFT RECIPIENTS (RAR)}

p53 mutations have also been found at high frequencies in skin cancers from patients with the genetic disorder Xeroderma Pigmentosum (Dumaz et al., 1993; Sato et al., 1993). Studies by Sato et al. (1993) revealed that 5 of 8 XP skin cancers had $p 53$ mutations and of the 6 mutations seen, 2 were $\mathrm{C} \rightarrow \mathrm{T}$ transitions and 2 were $\mathrm{CC} \rightarrow \mathrm{TT}$ double base substitutions. Dumaz et al. (1993) showed that $p 53$ mutations were present in 17 of $43(40 \%)$ skin cancers from XP patients and $61 \%$ of these mutations were tandem $\mathrm{CC} \rightarrow \mathrm{TT}$ base substitutions.

Immunosuppressed recipients of renal allografts (RAR) are also at much higher risk for skin cancer development. Over-expression of p53 protein and p53 mutations has been detected in large proportion of SCCs and pre-malignant lesions in RAR patients. In one study, accumulated p53 was present in $41 \%$ of premalignant keratosis, $65 \%$ of intraepidermal carcinomas and 56\% of squamous cell carcinomas from RAR patients (Stark et al., 1994). McGregor et al. (1997) has shown similarly high incidence of p53 mutations in non-melanoma skin tumors from RAR patients and sporadic NMSC from immune-competent patients: $48 \%$ and $63 \%$ respectively. $75 \%$ of all mutations in transplant patients and $100 \%$ mutations in non-transplant tumors were 
UV-signature mutations. Some evidence suggest that arginine/arginine genotype at a common polymorphism site at $p 53$ codon 72 may confer a susceptibility to the development of NMSC in RAR patients (McGregor et al., 2002). Finally, some evidence suggest a role for human papillomavirus (HPV) and its p53 protein-inhibitory activity in skin carcinogenesis within the immunosuppressed population (Purdie et al., 1999).

\section{P53 MUTATIONS ARE AND EARLY EVENT IN UV CARCINOGENESIS IN HUMAN AND MOUSE SKIN}

Mutations in p53 arise early in UV-induced skin cancer (Campbell et al., 1993; Ziegler et al., 1994; Berg et al., 1996; Jonason et al., 1996) and have been identified in normal sunexposed skin (Nakazawa et al., 1994; Jonason et al., 1996) as well as UV-irradiated mouse skin (Ananthaswamy et al., 1997). This differs from other cancers such as colon cancer in that p53 mutations are a late event marking the progression from a late adenoma to a carcinoma (Fearon and Vogelstein, 1990) as well as with melanoma marking the progression to a higher grade malignancy (Hussein et al., 2003). Non-cancerous skin adjacent to cancerous tumors has been shown to harbor p53 mutations that are different from those contained within the tumor (Kanjilal et al., 1995; Ren et al., 1996). Actinic keratosis carries p53 mutations at about 60\% with $89 \%$ of them UV signature type mutations. This can suggest that actinic keratosis is a clonal expansion of the cells that already contain the p53 mutation. Recent data investigating the role of clonal expansion suggests that it is more involved than hyperproliferation. Brash et al. (2005) has shown that UV not only can induce mutations, but that it drives clonal expansion of these cells by inducing apoptosis in surrounding normal cells and creating a microenvironment in need of repopulating. Thus the repopulation is an enrichment for the deathresistant mutant cells. Using a mouse model that over-expresses Survivin, a molecule that functions in suppressing apoptosis, clonal expansion of mutated cells was suppressed due to the reduced apoptotic death of the surrounding normal cells within the micro-environment (Brash et al., 2005).

\section{MECHANISMS OF CLONAL EXPANSION OF p53 MUTANT KERATINOCYTES}

A murine model of UV-induced carcinogenesis allowed a unique opportunity for investigating the fate of p53-mutant keratinocytes during various stages of skin cancer development. In skin of hairless mice, $p 53$ mutations induced by chronic UV exposure could be detected by allelespecific PCR as early as one week after initiation of the experiment, with $100 \%$ animals incurring p53 mutations after eight weeks of UV treatment (Ouhtit et al., 2000). Two to three weeks after beginning the UV treatment, clones of keratinocytes carrying mutant p53 can be already visualized using immunohistochemical assays (Berg et al., 1996; Rebel et al., 2001; Zhang et al., 2001). As a tumor promoter, UV induces cell proliferation by stimulating the production of various growth factors and cytokines, as well as activation of their receptors (Coffer et al., 1995; De Meyts et al., 1995; Rosette and Karin, 1996; Bender et al., 1997; Kuhn et al., 1999; Jost et al., 2000; Peus et al., 2000; Walterscheid et al., 2002). Repeated exposure of skin to UV radiation therefore results in clonal expansion of initiated p53-mutant cells (Berg et al., 1996; Rebel et al., 2001; Zhang et al., 2001). Brash and colleagues have shown that every successive UVB exposure allows p53-mutant keratinocytes to colonize adjacent epidermal stem-cell compartments without incurring additional mutations (Zhang et al., 2001). Two mechanisms are believed to contribute to selective expansion of p53-mutant cells: their resistance to UV-induced apoptosis, and their proliferative advantage over normal keratinocytes in response to stimulation with UV. Indeed, single UV exposure was shown to stimulate the proliferation of $p 53$-mutant cells while inducing apoptosis in normal keratinocytes in culture and in artificial skin models (Ziegler et al., 1994; Oda et al., 2000; Mudgil et al., 2003). However, chronic UV irradiation of skin quickly induces apoptosisresistance and stimulates hyperproliferation throughout the epidermis as an adaptive response 
(Ouhtit et al., 2000). The mechanism of selective proliferative advantage of $p 53$-mutant cells is yet unclear, but it may be a critical factor promoting clonal expansion of initiated cells.

One mechanism that may contribute to expansion of initiated keratinocytes is the deregulation of UV-induced Fas/Fas-Ligand mediated apoptosis in skin. Hill et al. (1999) showed that accumulation of $p 53$ mutations in the epidermis of Fas $L$ deficient mice occurred at much higher frequency compared with wild-type mice after chronic UV irradiation. Authors concluded that FasL-mediated apoptosis is important for skin homeostasis, and that the dysreguration of FasFasL interactions may be central to the development of skin cancer. Ouhtit et al. (2000) further found that in skin of chronically-irradiated SKH-hr1 mice, the progressive decrease of FasL expression was paralleled by accumulation of $\mathrm{p} 53$ mutations and the decrease in a number of apoptotic cells. These findings suggest that chronic UV exposure would induce a loss of FasL expression and a gain in $p 53$ mutations, leading to dysregulation of apoptosis, expansion of mutated keratinocytes, and initiation of skin cancer.

While patches of p53-mutant keratinocytes grow in density and size while UV treatment continues, they decline rapidly once the UV exposures are ceased (Berg et al., 1996; Rebel et al., 2001; Remenyik et al., 2003) Remeynic et al. (2003) showed that regression of precancerous p53-positive clones occurs due to mechanisms other than antigen-specific immunity, proceeding with similar kinetics in the skin of $\mathrm{Ragl}^{-/-}$antigen-specific immunity incompetent mice and their wild-type counterparts. Our preliminary results suggest that elimination of p53mutated keratinocytes occurs due to normal skin turnover.

Both, continued and discontinued regiments of chronic UV treatment ultimately result in skin tumor development with $100 \%$ incidence, although the kinetics of tumor occurrence is delayed in the later case (de Gruijl and van der Leun, 1991). De Gruijl and coworkers have used a mathematical model that relates tumor occurrence to the daily dose of UV and the time needed to contract tumors. This model also offers prediction of skin cancer susceptibility depending on the load of p53-mutated keratinocyte clones in skin (Rebel et al., 2001). Thus these studies suggest that skin cancer development can be delayed but not abrogated upon further avoidance of exposure to UV.

\section{INHIBITION OF UV-INDUCED p53 MUTATIONS PROTECTS AGAINST SKIN CANCER IN MICE}

Our studies have shown that $p 53$ mutations can be detected in UV-irradiated mouse skin months before the gross appearance of skin tumors suggesting that $p 53$ mutations can serve as a surrogate early biological endpoint in skin cancer prevention studies (Ananthaswamy et al., 1997; Ananthaswamy et al., 1999). To determine whether there is an association between reduction of UV-induced $p 53$ mutations and protection against skin cancer, sunscreens (SPF-15 to 22) were applied onto the shaved dorsal skin of $\mathrm{C} 3 \mathrm{H}$ mice $30 \mathrm{~min}$ before each exposure to $4.54 \mathrm{~kJ} / \mathrm{m}^{2}$ of UVB (290-400 nm) radiation. Control mice were treated 5 days/wk with UV only or vehicle + UV. p53 mutation analysis indicated that mice exposed to UV only or vehicle + UV for $16 \mathrm{wk}$ (cumulative exposure to $359 \mathrm{~kJ} / \mathrm{m}^{2}$ of UVB) developed $p 53$ mutations at a frequency of 56-69\%, respectively, but less than 5\% of mice treated with sunscreens + UV showed evidence of $p 53$ mutations. More importantly, $100 \%$ of mice that received a cumulative dose of $1,000 \mathrm{~kJ} / \mathrm{m}^{2}$ of UVB only, or vehicle + UVB developed skin tumors, whereas, the probability of tumor development in all the mice treated with the sunscreens $+1,000 \mathrm{~kJ} / \mathrm{m}^{2}$ of UVB was $2 \%$ and mice treated with sunscreens $+1,500 \mathrm{~kJ} / \mathrm{m}^{2}$ of UVB was $15 \%$. These results demonstrate that the sunscreens used in this study not only protect mice against UV-induced p53 mutations, but also against skin cancer. Because of this association, it was concluded that inhibition of $p 53$ mutations is a useful early biologic endpoint of photoprotection against an important initiating event in UV carcinogenesis. 


\section{p53 INFLUENCE ON DOWNSTREAM MOLECULES}

P53-related genes, p63 and p73, share functional and structural properties with the p53 tumor suppressor, but their role is less defined (Hagiwara et al., 1999). It was believed that $\mathrm{p} 63$ and p73 were linked to apoptotic activity not tumor suppression although they both can activate p53 target genes. Recently it has been shown that p63 and p73 have a role in tumor suppression as well as apoptosis. Direct evidence was provided as tumors from mice heterozygous for combinations of p53-related genes exhibit a high frequency of loss of heterozygosity (Flores et al., 2005). This allelic loss leads to more aggressive tumor types than the p53-/- tumors described by Jacks et al. 1994. Additionally, p63 and p73 tumor suppressor activity is unique to various tissue types. Epithelial tissues display a high expression of p63 and p73, while p53 is ubiquitously expressed, making p63 and p73 activity very relevant to the suppression/ development of cutaneous carcinomas as loss of expression of p63 and/or p73 has been noted in several squamous cell carcinomas (Chen et al., 2003).

More recent data investigating the role of p53 in UV-induced skin carcinogenesis has revealed other factors that are important to mention, such as the molecular downstream targets of p53: MDM2, GADD45, and p21CIP/WAF1. Murine double minute 2 (MDM2) protein is a transcriptional target of $\mathrm{p} 53$, which binds to the $\mathrm{N}$-terminus of $\mathrm{p} 53$ to promote degradation through the ubiquitin-proteasome pathway (Oliner et al., 1993; Haupt et al., 1997; Kubbutat et al., 1997; Giaccia and Kastan, 1998). Under normal cellular circumstances, in the presence of DNA damaging agents, p53 protein is stabilized by inhibition of the Mdm2-mediated p53 ubiquination (Weissman, 1997). Growth arrest and DNA damage-inducible gene 45

(GADD45) is a member of a group of genes induced in response to growth-arrest signals and it is a p53 regulated gene that can suppress cell growth. Loss of GADD45 results in reduced nucleotide excision repair activity (Korabiowska et al., 1999). p21CIP/WAF1 is a moderator of p53-mediated cell-cycle arrest, by directly interfering with DNA synthesis by binding to PCNA. Its role is largely unknown, but there are two observations to support its importance. First, the $\mathrm{p} 21 \mathrm{CIP} / \mathrm{WAF} 1$ promoter has a 553 protein-binding site. Secondly, there is a significant increase in p21CIP/WAF1 mRNA following UVR in cells with intact p53, but not in cells with mutant p53 (Hussein, 2005).

Calpains are calcium-dependent cytoplasmic proteases that are involved in various cellular functions, including exocytosis, cell fusion, apoptosis, and the differentiation and proliferation of keratinocytes. Inhibition of calpains has been correlated with the enhanced stability of the p53 protein suggesting that the calpain system can also cleave the p53 protein (Kubbutat and Vousden, 1997). Several studies have shown that calpains cleave the p53 protein to generate an N-terminally truncated protein (Kubbutat and Vousden, 1997; Pariat et al., 1997). In vitro addition of calpastatin, a calpain inhibitor, to reconstructed human epidermis resulted in the total inhibition of proteolysis of $\mathrm{p} 53$ and an increase in Mdm2 expression, binding, and ultimate stabilization of p53 in response to UV irradiation (Gelis et al., 2005).

\section{SUMMARY}

Approximately 80,000 pyrimidine dimers per cell are induced in human epidermis in one hour of sunlight exposure (Setlow, 1982). Fortunately, cells are equipped with a variety of mechanisms that constantly monitor and repair most of the damage inflicted by UV light. However, occasional mistakes in DNA repair and replication can introduce mutations in the genome. Accumulation of several mutations in key genes due to chronic exposure to sunlight can lead to the development of skin cancer. Mutations in ras oncogenes do not appear to be as important as mutations in the $p 53$ tumor suppressor gene in skin cancer development. Since skin cancers do not arise immediately after exposure to UV light, mutated ras or $p 53$ genes must remain latent for long periods of time. It is clear that the p53 gene has a role in early 
events of pre-malignant lesions and involvement through clonal expansion with progression into a tumorigenic condition. While there is an enormous amount of data to support this as evident in this review, new discoveries in the involvement of p53 are being made everyday. It is also clear that p53 has an expanding family of related genes, is involved in many pathways, and has numerous functions. P53 is also involved in not only NMSC, but plays a role in melanoma as well as numerous other cancers. It is no wonder that p53 has been coined "guardian of the genome."

\section{Acknowledgements}

Supported by National Cancer Institute grants CA 46523 and U01 CA105345, National Institute of Environmental Health Sciences Center Grant ES07784, and The University of Texas M. D. Anderson Cancer Center institutional core grant CA 16672. C.L.B was supported by NIH Grant P50 CA093459.

\section{References}

Agar NS, Halliday GM, Barnetson RS, Ananthaswamy HN, Wheeler M, Jones AM. The basal layer in human squamous tumors harbors more UVA than UVB fingerprint mutations: a role for UVA in human skin carcinogenesis. Proc Natl Acad Sci USA 2004;101:4954-4959. [PubMed: 15041750]

Ananthaswamy HN, Fourtanier A, Evans RL, Tison S, Medaisko C, Ullrich SE, Kripke ML. p53 Mutations in hairless SKH-1 mouse skin tumors induced by a solar simulator. Photochem Photobiol 1998;67:227-232. [PubMed: 9487800]

Ananthaswamy HN, Loughlin SM, Cox P, Evans RL, Ullrich SE, Kripke ML. Sunlight and skin cancer: inhibition of p53 mutation in UV-irradiated mouse skin by sunscreens. Nature Med 1997;3:510-514. [PubMed: 9142118]

Ananthaswamy HN, Ullrich SE, Mascotto RE, Fourtanier A, Loughlin SM, Kashkina P, Bucana CD, Kripke ML. Inhibition of solar simulator-induced p53 mutations and protection against skin cancer development in mice by sunscreens. J Invest Dermatol 1999;112:763-768. [PubMed: 10233769]

Basset-Seguin N, Moles JP, Mils V, Dereure O, Guihou JJ. TP53 tumor suppressor gene and skin carcinogenesis. J Invest Dermatol 1994;103:102S-106S. [PubMed: 7963669]

Bender K, Blattner C, Knebel A, Iordanov M, Herrlich P, Rahmsdorf HJ. UV-induced signal transduction. J Photochem Photobiol B 1997;37:1-17. [PubMed: 9043093]

Berg RJW, van Kranen HJ, Rebel HG, de Vries A, van Vloten WA, Van Kreijl CF, van der Leun JC, de Gruijl FR. Early p53 alterations in mouse skin carcinogenesis by UVB radiation:

immunohistochemical detection of mutant p53 protein in clusters of preneoplastic epidermal cells. Proc Natl Acad Sci USA 1996;93:274-278. [PubMed: 8552621]

Bolshakov S, Walker CM, Strom SS, Selvan MS, Clayman GL, El-Naggar A, Lippman SM, Kripke ML, Ananthaswamy HN. p53 mutations in human aggressive and nonaggressive basal and squamous cell carcinoma. Clin Cancer Res 2003;9:228-234. [PubMed: 12538474]

Brash DE, Rudolph JA, Simon JA, Lin A, McKenna GJ, Baden HP, Halperin AJ, Ponten J. A role for sunlight in skin cancer: UV-induced p53 mutations in squamous cell carcinoma. Proc Natl Acad Sci USA 1991;88:10124-12128. [PubMed: 1946433]

Brash DE, Zhang W, Grossman D, Takeuchi S. Colonization of adjacent stem cell compartments by mutant keratinocytes. Seminars in Cancer Biology 2005;15:97-102. [PubMed: 15652454]

Brugarolas J, Chandrasekaran C, Gordon JI, Beach D, Jacks T, Hannon GT. Radiation-induced cell cycle arrest compromised by p21 deficiency. Nature 1995;377:552-557. [PubMed: 7566157]

Burns PA, Kemp CJ, Gannon JV, Lane DP, Bremner R, Balmain A. Loss of heterozygosity and mutational alterations of the p53 gene in skin tumours of interspecific hybrid mice. Oncogene 1991;6:23632369. [PubMed: 1766680]

Campbell C, Quinn AG, Ro YS, Angus B, Rees JL. p53 mutations are common and early events that precede tumor invasion in squamous cell neoplasia of the skin. J Invest Dermatol 1993;100:746-748. [PubMed: 8496613]

Chen YK, Huse SS, Lin LM. Differential expression of p53, p63 and p73 proteins in human buccal squamous-cell carcinomas. Clin Otolaryngol 2003;28:451-455. [PubMed: 12969350] 
Coffer PJ, Burgering BM, Peppelenbosch MP, Bos JL, Kruijer W. UV activation of receptor tyrosine kinase activity. Oncogene 1995;11:561-569. [PubMed: 7543196]

de Gruijl FR, van der Leun JC. Development of skin tumors in hairless mice after discontinuation of ultraviolet irradiation. Cancer Res 1991;51:979-984. [PubMed: 1988142]

De Meyts P, Urso B, Christoffersen CT, Shymko RM. Mechanism of insulin and IGF-I receptor activation and signal transduction specificity. Receptor dimer cross-linking, bell-shaped curves, and sustained versus transient signaling. Ann N Y Acad Sci 1995;766:388-401. [PubMed: 7486684]

Donehower LA, Harvey M, Slagle BL, McArthur MJ, Montgomery CA Jr, Butel JS, Bradley A. Mice deficient for p53 are developmentally normal but susceptible to spontaneous tumours. Nature 1992;356:215-212. [PubMed: 1552940]

Dumaz N, Drougard C, Sarasin A, Daya-Grosjean L. Specific UV-induced mutation spectrum in the p53 gene of skin tumors from DNA-repair-deficient xeroderma pigmentosum patients. Proc Natl Acad Sci USA 1993;90:10529-10533. [PubMed: 8248141]

Dumaz N, van Kranen HJ, de Vries A, Berg RJ, Wester PW, Van Kreijl CF, Sarasin A, Daya-Grosjean L, de Gruijl FR. the role of UV-B light in skin carcinogenesis through the analysis of p53 mutations in squamous cell carcinomas of hairless mice. Carcinogenesis 1997;18:897-904. [PubMed: 9163673]

Fearon ER, Vogelstein B. A genetic model for colorectal tumorigenesis. Cell 1990;61:759-767. [PubMed: 2188735]

Flores ER, Sengupta S, Miller JB, Newman JJ, Bronson R, Crowley D, Yang A, McKeon F, Jacks T. Tumor predisposition in mice mutant for $p 63$ and $p 73$ : Evidence for broader tumor suppressor functions for the $p 53$ family. Cancer Cell 2005;7:363-373. [PubMed: 15837625]

Fritsche M, Haessler C, Brandner G. Induction of the nuclear accumulation of the tumor suppressor gene p53 by DNA damaging agents. Oncogene 1993;8:307-318. [PubMed: 8426740]

Gelis C, Mavon A, Vicendo P. The Contribution of Calpains in the Downregulation of Mdm2 and p53 Proteolysis in Reconstituted Human epidermis in Response to Solar Irradiation. Photochem Photobiol. 2005

Giaccia AJ, Kastan MB. The complexity of p53 modulation emerging patterns from divergent signals. Genes Dev 1998;12:2973-2983. [PubMed: 9765199]

Greenblatt MS, Bennett WP, Hollstein M, Harris CC. Mutations in the p53 tumor suppressor gene: clues to cancer etiology and molecular pathogenesis. Cancer Res 1994;54:4855-4878. [PubMed: 8069852]

Hagiwara K, McMenamin MG, Miura K, Harris CC. Mutational analysis of the p63/p73L/p51/p40/ CUSP/KET gene in human cancer cell lines using intronic primers. Cancer Res 1999;59:4165-4169. [PubMed: 10485447]

Hall PA, McKee PH, Menage HP, Dover R, Lane DP. High levels of p53 protein in UV-irradiated normal human skin. Oncogene 1993;8:203-207. [PubMed: 8093810]

Harris CC. Structure and function of the p53 tumor suppressor gene: clues for rational cancer therapeutic strategies. J Natl Cancer Inst 1996;88:1442-1455. [PubMed: 8841019]

Hartwell LH, Weinert TA. Checkpoints: controls that ensure the order of cell cycle events. Science 1989;246:629-634. [PubMed: 2683079]

Haupt Y, Maya R, Kazaz A, Oren M. Mdm2 promotes the rapid degradation of p53. Nature 1997;387:296-299. [PubMed: 9153395]

Healy E, Reynolds NJ, Smith MD, Campbell C, Farr PM, Rees JL. Dissociation of erythemia and p53 expression in human skin following UVB irradiation, and induction of p53 protein and mRNA following application of skin irritants. J Invest Dermatol 1994;103:493-499. [PubMed: 7930673]

Hill LL, Ouhtit A, Loughlin SM, Kripke ML, Ananthaswamy HN, Owen-Schaub LB. Fas ligand: a sensor for DNA damage critical in skin cancer etiology. Science 1999;285:898-900. [PubMed: 10436160]

Hussein MR. Ultraviolet radiation and skin cancer: molecular mechanisms. J Cutan Pathol 2005;32:191205. [PubMed: 15701081]

Hussein MR, Haemel AK, Wood GS. Apoptosis and melanoma: molecular mechanisms. J Pathol 2003;199:275. [PubMed: 12579529]

Jacks T, Remington L, Williams BO, Schmitt EM, Halachmi S, Bronson RT, Weinberg RA. Tumor spectrum analysis in p53-mutant mice. Curr Biol 1994;4:1-7. [PubMed: 7922305] 
Jiang W, Ananthaswamy HN, Muller HK, Kripke ML. p53 protects against skin cancer induction by UVB radiation. Oncogene 1999;18:4247-4253. [PubMed: 10435637]

Jonason AS, Kunala S, Price GL, Restifo RJ, Spinelli HM, Persing JA, Leffell DJ, Tarone RE, Brash DE. Frequent clones of p53-mutated keratinocytes in normal human skin. Proc Natl Acad Sci USA 1996;93:14025-14029. [PubMed: 8943054]

Jost M, Kari C, Rodeck U. The EGF receptor - and essential regulator of multiple epidermal functions. Eur J Dermatol 2000;10:505-510. [PubMed: 11056418]

Kamijo, t; Weber, JD.; Zambetti, G.; Zindy, F.; Roussel, MF.; Sherr, CJ. Functional and physical interactions of the ARF tumor suppressor with p53 and Mdm2. Proc Natl Acad Sci USA 1998;95:8292-8297. [PubMed: 9653180]

Kanjilal S, Pierceall WE, Cummings KK, Kripke ML, Ananthaswamy HN. High frequency of p53 mutations in ultraviolet radiation-induced murine skin tumors: evidence for strand bias and tumor heterogeneity. Cancer Res 1993;53:2961-2964. [PubMed: 8319202]

Kanjilal S, Strom SS, Clayman GL, Weber RS, el-Naggar AK, Kapur V, Cummings KK, Hill LA, Spitz MR, Kripke ML. p53 mutations in nonmelanoma skin cancer of the head and neck: molecular evidence for field cancerization. Cancer Res 1995;55:3604-3609. [PubMed: 7627969]

Kastan MB, Onyekwere O, Sidransky D, Vogelstein B, Craig W. Participation of p53 protein in the cellular response to DNA damage. Mol Cell Biol 1991;51:6304-6311.

Kastan MB, Zhan Q, El-Deiry S, Carrier F, Jacks T, Walsh W, Plunkett BS, Vogelstein B, Fornace AJ Jr. A mammalian cell cycle checkpoint pathway utilizing p53 and Gadd45 is defective in ataxiatelangiectasia. Cell 1992;71:587-597. [PubMed: 1423616]

Kemp CJ, Donehower LA, Bradley A, Balmain A. Reduction of p53 gene dosage does not increase initiation or promotion but enhances malignant progression of chemically induced skin tumors. Cell 1993;74:813-822. [PubMed: 8374952]

Kemp CJ, Wheldon T, Balmain A. p53-deficient mice are extremely susceptible to radiation-induced tumorigenesis. Nat Genet 1994;8:66-69. [PubMed: 7987394]

Korabiowska M, Brinck U, Betke H, Droese M, Berger H. Growth arrest DNA damage gene expression in naevi. In Vivo 1999;13:247-250. [PubMed: 10459501]

Kress S, Sutter C, Strickland PT, Mukhtar H, Schweizer J, Schwarz M. Carcinogen-specific mutational pattern in the p53 gene in ultraviolet B radiation-induced squamous cell carcinomas of mouse skin. Cancer Res 1992;52:6400-6403. [PubMed: 1423288]

Kubbutat MH, Jones SN, Vousden KH. Regulation of p53 stability by Mdm2. Nature 1997;387:299_ 303. [PubMed: 9153396]

Kubbutat MH, Vousden KH. Proteolytic cleavage of human p53 by calpain: a potent regulator of protein stability. Mol Cell Biol 1997;17:460-468. [PubMed: 8972227]

Kuerbitz SJ, Plunkett BS, Walsh WV, Kastan MB. Wild-type p53 is a cell cycle checkpoint determinant following irradiation. Proc Natl Acad Sci USA 1992;89:7491-7495. [PubMed: 1323840]

Kuhn C, Hurwitz SA, Kumar MG, Cotton J, Spandau DF. Activation of the insulin-like growth factorreceptor promotes the survival of human keratinocytes following ultraviolet B irradiation. Int $\mathbf{J}$ Cancer 1999;80:431-438. [PubMed: 9935186]

Lamb P, Crawford L. Characterization of the human p53 gene. Mol Cell Biol 1986;6:1379-1385. [PubMed: 2946935]

Lane D. p53, guardian of the genome. Nature 1992;358:15-16. [PubMed: 1614522]

Levine AJ. p53, the cellular gatekeeper for growth and division. Cell 1997;88:323-331. [PubMed: 9039259]

Levine AJ, Momand J, Finlay CA. The $p 53$ tumor suppressor gene. Nature 1991;351:453-456. [PubMed: 2046748]

Malkin D, Li FP, Strong LC, Fraumeni JF Jr, Nelson CE, Kim DH, Kassel J, Gryka MA, Bischoff FZ, Tainsky MA. Germ line p53 mutations in a familial syndrome of breast cancer, sarcomas, and other neoplasms. Science 1990;250:1233-1238. [PubMed: 1978757]

Maltzman W, Czyzyk L. UV irradiation stimulates levels of p53 cellular tumor antigen in nontransformed mouse cells. Mol Cell Biol 1984;4:1689-1694. [PubMed: 6092932] 
McGregor JM, Berkhout RJ, Rozycka M, ter Schegget J, Bouwes Bavinck JN, Brooks L, Crook T. p53 mutations implicate sunlight in post-transplant skin cancer irrespective of human papillomavirus status. Oncogene 1997;15:1737-1740. [PubMed: 9349508]

McGregor JM, Harwood CA, Brooks L, Fisher SA, Kelly DA, O'nions J, Young AR, Surentheran T, Breuer J, Millard TP, Lewis CM, Leigh IM, Storey A, Crook T. Relationship between p53 codon 72 polymorphism and susceptibility to sunburn and skin cancer. J Invest Dermatol 2002;119:84-90. [PubMed: 12164929]

Mitchell DL. the relative cytotoxicity of (6-4) photoproducts and cyclobutane dimers in mammalian cells. Photochem Photobiol 1988;48:51-57. [PubMed: 3217442]

Mitchell DL, Nairn RS. The biology of the 6-4 photoproducts and cyclobutane dimers in mammalian cells. Photochem Photobiol 1989;49:805-819. [PubMed: 2672059]

Moles JP, Moyret C, Guillot B, Jeanteur P, Guihou JJ, Theillet C, Basset-Saguin N. p53 gene mutations in human epithelial skin cancers. Oncogene 1993;8:583-588. [PubMed: 8437842]

Mudgil AV, Segal N, Andriani F, Wang Y, Fusenig NE, Garlick JA. Ultraviolet B irradiation induces expansion of intraepithelial tumor cells in a tissue model of early cancer progression. J Invest Dermatol 2003;121:191-197. [PubMed: 12839581]

Nakazawa H, English D, Randell PL, Nakazawa K, Martel N, Armstrong BK, Yamasaki H. UV and skin cancer: specific p53 gene mutation in normal skin as a biologically relevant exposure measurement. proc Natl Acad Sci USA 1994;91:360-364. [PubMed: 8278394]

Nelson MA, Einspahr JG, Alberts DS, Balfour CA, Wymer JA, Welch KL, Salasche SJ, Bangert JL, Grogan TM, Bozzo PO. Analysis of the p53 gene in human precancerous actinic keratosis lesions and squamous cell cancers. Cancer Lett 1994;85:23-29. [PubMed: 7923098]

Nelson WG, Kastan MB. DNA strand breaks: the DNA template alterations that trigger p53-dependent DNA damage response. Mol Cell Biol 1994;14:1815-1823. [PubMed: 8114714]

Oda K, Arakawa H, Tanaka T, Matsuda K, Tanikawa C, Mori T, Nishimori H, Tamai K, Tokino T, Nakamura Y, Taya Y. p53AIP1, a potential mediator of p53-dependent apoptosis, and its regulation by Ser-46-phosphorylated p53. Cell 2000;102:849-862. [PubMed: 11030628]

Oliner JD, Pietenpol JA, Thiallingam S, Gyuris J, Kinzler KW, Vogelstein B. Oncoprotein MDM2 conceals the activation domain of tumour suppressor p53. Nature 1993;362:857-860. [PubMed: 8479525]

Ouhtit A, Gorny A, Muller HK, Hill LL, Owen-Schaub L, Ananthaswamy HN. Loss of Fas-ligand expression in mouse keratinocytes during UV carcinogenesis. Am J Pathol 2000;157:1975-1981. [PubMed: 11106570]

Pariat M, Carillo S, Molinari M, Salvat C, Debussche L, Bracco L, Milner J, Piechaczyk M. Proteolysis by calpains: a possible contribution to degradation of p53. Mol Cell Biol 1997;17:2806-2815. [PubMed: 9111352]

Peus D, Vasa RA, Meves A, Beyerle A, Pittelkow MR. UVB-induced epidermal growth factor receptor phosphorylation is critical for downstream signaling and keratinocyte survival. Photochem Photobiol 2000;72:135-140. [PubMed: 10911738]

Pfeifer GP, You YH, Besaratinia A. Mutations induced by ultraviolet light. Mut Res 2005;571:19-31. [PubMed: 15748635]

Pierceall WE, Goldberg LH, Tainsky MA, Mukhopadhyay T, Ananthaswamy HN. Ras gene mutation and amplification in human nonmelanoma skin cancers. Mol Carcinog 1991a;4:196-202. [PubMed: 2064725]

Pierceall WE, Mukhopadhyay T, Goldberg LH, Ananthaswamy HN. Mutations in the p53 tumor suppressor gene in human cutaneous squamous cell carcinomas. Mol Carcinog 1991b;4:445-449. [PubMed: 1793482]

Purdie KJ, Pennington J, Proby CM, Khalaf S, de Villiers EM, Leigh IM, Storey A. The promoter of a novel human papillomavirus (HPV77) associated with skin cancer displays a UV responsiveness, which is mediated through a consensus p53 binding sequence. EMBO J 1999;18:5359-5369. [PubMed: 10508168]

Rady P, Scinicariello F, Wagner RF Jr, Tyring SK. p53 mutations in basal cell carcinomas. Cancer Res 1992;52:3804-3806. [PubMed: 1617650] 
Rebel H, Mosnier LO, Berg RJ, Westerman-de Vries A, van Steeg H, van Kranen HJ, de Gruijl FR. Early p53-positive foci as indicators of tumor risk in ultraviolet-exposed hairless mice: kinetics of induction, effects of DNA repair deficiency, and p53 heterozygosity. Cancer Res 2001;61:977-983. [PubMed: 11221893]

Remenyik E, Wikonkal NM, Zhang W, Paliwal V, Brash DE. Antigen-specific immunity does not mediate acute regression of UVB-induced p53-mutant clones. Oncogene 2003;22:6369-6376. [PubMed: 14508517]

Ren ZP, Hedrum A, Ponten F, Nister M, Ahmadian A, Lundeberg J, Uhen M, Ponten J. Human epidermal cancer and accompanying precursors have identical p53 mutations different from p53 mutations in adjacent areas of clonally expanded non-neoplastic keratinocytes. Oncogene 1996;12:765-773. [PubMed: 8632898]

Rosette C, Karin M. Ultraviolet light and osmotic stress: activation of the JNK cascade through multiple growth factor and cytokine receptors. Science 1996;274:1194-1197. [PubMed: 8895468]

Sato M, Nishigori C, Zghal M, Yagi T, Takebe H. Ultraviolet-specific mutations in the p53 gene in skin tumors in xeroderma pigmentosum patients. Cancer Res 1993;53:2944-2946. [PubMed: 8319200]

Setlow RB. DNA repair, ageing, and cancer. Natl Cancer Inst Monogr 1982;60:249-255. [PubMed: 7121571]

Setlow RB, Carrier WL. Pyrimidine dimers in ultraviolet-irradiated DNA's. J Mol Biol 1966;17:237254. [PubMed: 4289765]

Smith ML, Fornace AJ Jr. p53-mediated protective responses to UV irradiation. Proc Natl Acad Sci USA 1997;94:12255-12257. [PubMed: 9356435]

Stark LA, Arends MJ, McLaren KM, Benton EC, Shahidullah H, Hunter JA, Bird CC. Accumulation of p53 is associated with tumour progression in cutaneous lesions of renal allograft recipients. $\mathrm{Br} \mathrm{J}$ Cancer 1994;70:662-667. [PubMed: 7917913]

Stern RS, Bolshakov S, Natataj AJ, Ananthaswamy HN. p53 mutation in nonmelanoma skin cancers occurring in psoralen ultraviolet a-treated patients: evidence for heterogeneity and field cancerization. J Invest Dermatol 2002;119:522-526. [PubMed: 12190879]

Tommasi S, Denissenko MF, Pfeifer GP. Sunlight induces pyrimidine dimers preferentially at 5methylcytosine bases. Cancer Res 1997;57:4727-4730. [PubMed: 9354431]

van der Riet P, Karp D, Farmer E, Wei Q, Grossman L, Tonkino K, Ruppert JM, Sidransky D. Progression of basal cell carcinoma through loss of chromosome $9 \mathrm{q}$ and inactivation of a single p53 allele. Cancer Res 1994;54:25-27. [PubMed: 8261448]

van Kranen HJ, Westerman A, Berg RJW, Kram N, Van Kreijl CF, Wester PW, de Gruijl FR. Dosedependent effects of UVB-induced skin carcinogenesis in hairless p53 knockout mice. Mut Res 2005;571:81-90. [PubMed: 15748640]

Vogelstein B, Kinzler KW. p53 function and dysfunction. Cell 1992;70:523-526. [PubMed: 1505019]

Walterscheid JP, Ullrich SE, Nghiem DX. Platelet-activating factor, a molecular sensor for cellular damage, activates systemic immune suppression. J Exp Med 2002;195:171-179. [PubMed: 11805144]

Weissman AM. Regulating protein degradation by ubiquination. Immunol Today 1997;18:189-198. [PubMed: 9136456]

White E. Life, death, and the pursuit of apoptosis. Genes Dev 1996;10:1-15. [PubMed: 8557188]

Yonish-Roauch E, Reznitzky D, Lotem J, Sachs L, Kimchi A, Oren M. Wild type p53 induces apoptosis of myeloid leukemic cells that is inhibited by IL-6. Nature 1991;352:345-347. [PubMed: 1852210]

You YH, Lee DH, Yoon JH, Nakajima S, Yasui A, Pfeifer GP. Cyclobutane pyrimidine dimers are responsible for the vast majority of mutations induced by UVB irradiation in mammalian cells. J Biol Chem 2001;276:44688-44694. [PubMed: 11572873]

You YH, Szabo PE, Pfeifer GP. Cyclobutane pyrimidine dimers form preferentially at the major p53 mutational hotspot in UVB-induced mouse skin tumors. Carcinogenesis 2000;21:2113-2117. [PubMed: 11062176]

Zahn Q, Carrier F, Fornace AJ Jr. Induction of cellular p53 activity by DNA-damaging agents and growth arrest. Mol Cell Biol 1993;13:4242-4250. [PubMed: 8321226]

Zhang W, Remenyik E, Zelterman D, Brash DE, Wikonkal NM. Escaping the stem cell compartment: sustained UVB exposure allows p53-mutant keratinocytes to colonize adjacent epidermal 
proliferating units without incurring additional mutations. Proc Natl Acad Sci USA 2001;98:1394813953. [PubMed: 11707578]

Ziegler A, Jonason AS, Leffell DJ, Simon JA, Sharma HW, Kimmelman J, Remington L, Jacks T, Brash DE. Sunburn and p53 in the onset of skin cancer. Nature 1994;372:730-731. [PubMed: 7997257]

Ziegler A, Leffell DJ, Kunala S, Sharma HW, Gailani M, Simon JA, Halperin AJ, Baden HP, Shapiro

PE, Bale AE, Brash DE. Mutation hotspots due to sunlight in the p53 gene of nonmelanoma skin cancers. Proc Natl Acad Sci USA 1993;90:4216-4220. [PubMed: 8483937] 